2. Actual methods for obtaining vegetable oil from oilseeds / Ionescu M. et. al. // International Conference on Thermal Equipment, Renewable Energy and Rural Development. 2013. P. 167-172.

3. Extraction of oil from algae by solvent extraction and oil expeller method / Topare N. S. et. al. // International Journal of Chemical Sciences. 2011. Vol. 9, Issue 4. P. 1746-1750.

4. Hussain S., Shafeeq A., Anjum U. Solid liquid extraction of rice bran oil using binary mixture of ethyl acetate and dichloromethane // Journal of the Serbian Chemical Society. 2018. Vol. 83, Issue 7-8. P. 911-921. doi: http://doi.org/10.2298/jsc170704023h

5. Intensification Methods of Extracting Biologically Active Substances from Vegetative Raw Materials / Zhmatova G. V. et. al. // Transactions TSTU. 2005. Vol. 11, Issue 3. P. 701-707.

6. Improvement of Soybean Oil Solvent Extraction through Enzymatic Pretreatment / Grasso F. V. et. al. // International Journal of Agronomy. 2012. Vol. 2012. P. 1-7. doi: http://doi.org/ $10.1155 / 2012 / 543230$

7. Li H., Pordesimo L., Weiss J. High intensity ultrasound-assisted extraction of oil from soybeans // Food Research International 2004. Vol. 37, Issue 7. P. 731-738. doi: http://doi.org/10.1016/ j.foodres.2004.02.016

8. Ultrasonic Extraction of Oil from Caesalpinia spinosa (Tara) Seeds / Li Z. et. al. // Journal of Chemistry. 2016. Vol. 2016. P. 1-6. doi: http://doi.org/10.1155/2016/1794123
9. Choice of solvent extraction technique affects fatty acid composition of pistachio (Pistacia vera L.) oil / Abdolshahi A et. al. // Journal of Food Science and Technology. 2013 Vol. 52, Issue 4. P. 2422-2427. doi: http://doi.org/10.1007/ s13197-013-1183-8

10. Novitskiy B. G. Primenenie akusticheskikh kolebaniy v khimikotekhnologicheskikh protsessakh. Moscow: Khimiya, 1983. 192 p.

Karachun Volodimir, Doctor of Technical Sciences, Professor Department of Biotechnics and Engineering, National Technical University of Ukraine «Igor Sikorsky Kyiv Polytechnic Institute», Ukraine, e-mail: karachun11@i.ua, ORCID: http://orcid.org/00000002-6080-4102

Ruzhinska Ludmila, PhD, Associate Professor, Department of Biotechnics and Engineering, National Technical University of Ukraine «Igor Sikorsky Kyiv Polytechnic Institute»,Ukraine, e-mail: ruzhli@ukr.net, ORCID: http://orcid.org/0000-0003-1223-7649

Ostapenko Zhanna, Department of Biotechnics and Engineering, National Technical University of Ukraine «Igor Sikorsky Kyiv Polytechnic Institute», Ukraine, e-mail: zhanna.ost@gmail.com, ORCID: http://orcid.org/0000-0003-0949-9912

\section{Bondarenko Y., Bilyk 0., Kochubei-Lytvynenko O., Khalikova E., Fain A.}

\title{
INVESTIGATION OF INFLUENCE OF INULIN MADE FROM CYCORIA ON STRUCTURAL-MECHANICAL PROPERTIES OF WHEAT DOUGH
}

Хліб з пшеничного борошна за хімічним складом недостатньо збалансований за життєво важливими інгредієнтами. Одним з його недоліків є те, що при великому вмісті вуглеводів в ньому обмаль харчових волокон, тому перспективно збагачувати його інуліновмісними продуктами. Включення інуліну з цикорію в рецептуру пшеничного хліба здійснюватиме вплив на формування реологічних властивостей тіста, що впливатиме на якість готових виробів. Тому об'єктом досліджень у роботі було тісто з пшеничного борошна першого сорту, в рещептуру якого включено інулін з цикорію. Під час досліджень використовували інулін з иикорію «Соsиска» (Бельгія) в кількості 5, 10, 15 \% до маси борошна. Встановлено, що додавання інуліну зумовлює зростанню пружних властивостей тіста, особливо у разі підвищення дозування інуліну більше $10 \%$. Підвищення дозування інуліну до $15 \%$ і більше поряд з підвищенням пружнх характеристик знижує еластичність тіста, що обумовлює значне погіршання об'єму виробів. Доведено, що зменшення питомого об'єму виробів та підвищення пружних характеристик м'якушки є обмежувальними факторами застосування в рещептурі виробів інуліну в кількості більще 10 \% до маси борошна. Використання у рещептурі хліба інуліну в кількості 10 та 15 \% до маси борошна внаслідок підвищення пружніх властивостей тіста зумовлює значне погіршання об'єму виробів. Смак та аромат виробів з інуліном були властиві пшеничному хлібу. Завдяки включенню в рещептуру пшеничного хліба інуліну вироби набувають пребіотичних властивостей, однак ефективність використання інуліну для покращання якості готових виробів можлива за дозування 5 \% до маси борошна. Для більшого збагачення хлібобулочних виробів харчовими волокнами можна використовувати дозування інуліну 10 \% до маси борошна, але застосовувати при цьому технологічні заходи для покращання якості виробів.

Ключові слова: пшеничний хліб, інулін з цикорію, пружні властивості тіста, еластичність тіста.

\section{Introduction}

Recent studies have shown that in the nutrition of the population of Ukraine there is a shortage of polysaccharides, which leads to the development of various diseases such as cardiovascular, gastrointestinal, diabetes [1, 2]. One of the important polysaccharides, which have prebiotic properties, is inulin, which is abundantly contained in Jerusalem artichoke, yacon, dandelion, burdock, chicory, scorzonera [3-5]. Inulin-based products are relevant to enrich wheat bread as a product of mass consumption. In this direction, studies have been conducted [6], in which 
it is recommended to limit the dosage of inulin in the recipe of wheat bread to $5 \%$ by weight of flour. In [7], the authors used inulin in the technology of gluten-free bread. Labor researchers [8] optimized the recipe for wheat bread based on the combined use of calcium carbonate and inulin. In studies [9], regularities of the formation of the structural and mechanical properties of dough for dosing of inulin powders from Jerusalem artichoke and chicory in the amount of 2.5 and $5.0 \mathrm{~g}$ per $100 \mathrm{~g}$ of wheat flour were established. And in [10] it is noted that the use of inulin in the recipe of the wallpaper flour products can be limited to a dosage of $15 \%$. On this basis, it is important to conduct research on the establishment of the maximum possible dosing of inulin in the recipe of bread made from wheat flour, justifying its influence on the rheological properties of the dough. Therefore, the object of research in the work is the dough of wheat flour of the first grade, the recipe of which includes inulin from chicory. And the aim of research is establishing the effect of inulin made from chicory on the formation of the structural and mechanical properties of dough.

\section{Methods of research}

The studies used inulin from chicory «Cosucra» (Belgium). Inulin from chicory is a soluble dietary fiber, extracted from chicory roots. Inulin is a natural polysaccharide consisting of residues of $D$-fructose (up to $96 \%$ ) linked by a $\beta$-2-1-glycosidic bond. Inulin is a low-calorie $(1.3 \mathrm{kcal} / \mathrm{g})$ prebiotic fiber, a bifidostimulator in the intestine. This raw material has the appearance of a white powder, slightly sweet in taste, contains $96.3 \%$ of dry substances, $92.3 \%$ of which are inulin.

To assess the quality of bread with the addition of inulin made from chicory and establish its technologically possible dosing, a pilot laboratory baking was performed. During the study, the dough was prepared from first-grade flour with the addition of inulin in the amount of 5, 10 and $15 \%$ by weight of the flour. The control was a sample according to the following recipe: wheat flour of the first grade - $100 \mathrm{~g}$, yeast $-3 \%$, salt $-1.5 \%$. The dough was kneaded in an Esher kneader (Italy) for 4 minutes at the first speed and 7 minutes at the second speed. The dough was prepared by the straight-line method with a mass fraction of the dough's moisture content - $41 \%$. During the period of fermentation, dough was punched 60 and 120 minutes after mixing. Dough processing was carried out manually, dough was made in a cabinet and at a temperature of $38 \pm 2{ }^{\circ} \mathrm{C}$ and relative humidity of $78 \pm 2 \%$ until ready. Products were baked in cupboard ovens at a temperature of $220-240{ }^{\circ} \mathrm{C}$ with moistening of the baking chamber.

The quality of bread was assessed by physicochemical (specific volume, acidity) and organoleptic characteristics (appearance, surface of the crust, structure of porosity, taste, smell) [11]. Gas-retaining dough capacity was determined by changing the specific volume of $100 \mathrm{~g}$ of dough in the cylinder during the dough fermentation [12]. The elastic properties of the dough were studied on a Brabender farinograph (Sweden) and a Chopin alveograph (France) [12]. The results of experimental studies were subjected to statistical processing implemented using standard software packages Microsoft Office.

\section{Research results and discussion}

Structural and mechanical properties of the dough are determined by the balance between its elastic and viscoplastic characteristics. Elastic properties of the dough inhibit the development of its volume. Along with this contribute to the preservation of the formed dough pieces. The elasticity of dough causes the formation of foamy structure, plays an important role in the formation of porosity and volume of products. Reduced or excessive elasticity of the dough leads to a decrease in the volume of bread.

Research results obtained using the farinograph (Table 1) indicate that adding inulin increases the water-clay content of the dough, probably due to the high hydrophilic ability of fructose, which is a compound of inulin. This results in a lengthening of dough formation in the case of inulin application for 9.5-16.5 minutes. When dosing inulin compared to the control of dough dilution decreases, and in the case of dosing 5 and $10 \%$ by weight of inulin flour improves the elasticity of the dough. The greater elasticity of the dough with inulin is due to the fact that the formed solutions penetrate into the structure of the protein molecule, certain changes occur in the structure of protein molecules and the formation of complexes of fructose, which is part of inulin, with protein. The introduction of $15 \%$ of inulin as a result of higher hydrophilic ability leads to a decrease in water for the swelling of gluten, which impairs the hydration of proteins, increases their elasticity. Due to the fact that inulin, upon contact with water, causes the formation of a more viscous liquid phase of the dough than in the control, this reduces its dilution.

These alveograms (Table 2) indicate a decrease in elasticity and specific work of the deformation in the case of making inulin in the dough. Increasing the dosage of inulin decreases the elastic properties of the dough, as evidenced by a decrease in the $P / L$ ratio.

Table 1

Structural and mechanical properties of dough by farinograph, $n=3, p \leq 0.95$

\begin{tabular}{|l|c|c|c|c|}
\hline \multirow{2}{*}{ Indicators } & \multirow{2}{*}{ Control } & \multicolumn{4}{c|}{$\begin{array}{c}\text { Added inulin, } \\
\text { \% by weight of flour }\end{array}$} \\
\cline { 3 - 5 } & & 5 & 10 & 15 \\
\hline Consistency, unit & 500 & 500 & 500 & 500 \\
\hline Water gliding capacity, cm $3 / 100$ g & 57.5 & 57.4 & 61.1 & 63.9 \\
\hline Formation duration, min & 2.5 & 13 & 16.5 & 19.0 \\
\hline Elasticity, units appliance & 140 & 200 & 260 & 120 \\
\hline Stability, min & 5.0 & 10 & 15 & 20 \\
\hline $\begin{array}{l}\text { Dilution during mixing, 15 minutes } \\
\text { appliance }\end{array}$ & 70 & 10 & 20 & 35 \\
\hline
\end{tabular}

Table 2

The effect of inulin on the elastic properties of the dough (according to the alveograph), $n=3, p \leq 0.95$

\begin{tabular}{|l|c|c|c|c|}
\hline \multirow{2}{*}{ Indicators } & \multirow{2}{*}{ Control } & \multicolumn{3}{|c|}{ Added inulin, \% by weight of flour } \\
\cline { 3 - 5 } & & 5 & 10 & 15 \\
\hline Elasticity, $P, \mathrm{~mm}$ & 113 & 111 & 78 & 70 \\
\hline Stretchability, $L, \mathrm{~mm}$ & 77 & 46 & 38 & 33 \\
\hline$P / L$ & 1.47 & 2.41 & 2.05 & 1.88 \\
\hline Alveogram area, $5, \mathrm{~cm}^{2}$ & 19.5 & 15.1 & 13.7 & 14.6 \\
\hline $\begin{array}{l}\text { Specific work deformation, } \\
W, 10 \text { units of alveograph }\end{array}$ & 346 & 219 & 121 & 121 \\
\hline
\end{tabular}


Dough stretchability largely depends on its elasticity. Despite this, it is possible to assume the best gas-retaining ability of the dough samples; according to the alveograph, they had a higher expansibility index. To confirm this, changes in the volume of dough in a measuring cylinder of $500 \mathrm{~cm}^{3}$ at a temperature of $30{ }^{\circ} \mathrm{C}$ during 4 hours of fermentation we are investigated. It is established (Fig. 1) that with the introduction of $5 \%$ inulin, an improvement in the specific volume of dough is observed by $10 \%$ relative to the control. This is due to the improvement in the elasticity of the dough, along with a certain strengthening of the gluten carcass. With an increase in the dosage of inulin, the specific volume of dough decreases due to the development of more elastic properties of the dough.

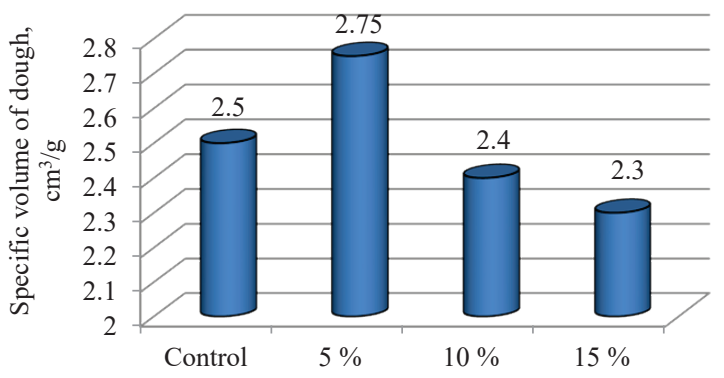

Fig. 1. Specific volume of dough

The dough system along with the elastic has viscoplastic properties. The residual strain that accumulates in it during fermentation causes the dough layers to shift relative to each other due to the destruction of the structural mesh. Excessive dough viscosity leads to insufficient crumbling, thick pore walls. Low viscosity can lead to the destruction of the pore walls, the confluence of small pores, the formation of uneven coarse porosity. It is established (Fig. 2) that the dough with $5 \%$ inulin running a little more than the control, and with increasing dosage there is less bleeding due to the increased viscosity of the dough and strengthening of gluten and this can cause the formation of a larger bottom-to-diameter ratio $(\mathrm{H} / \mathrm{D})$ of bread.

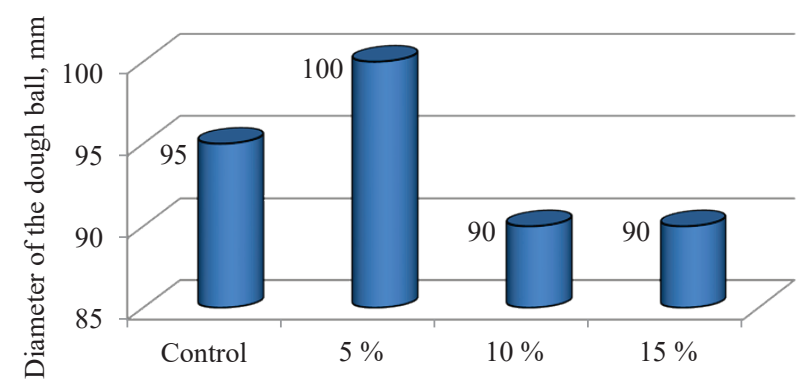

Fig. 2. Running of dough balls

The quality of bakery products, their specific volume, dimensional stability, crumb structure and elasticity largely depend on the structural and mechanical properties of the dough. The obtained patterns of influence of inulin on the formation of the structural and mechanical properties of dough determine the formation of the quality of finished products (Table 3, Fig. 3). According to the results of the laboratory dough baking, it is established that at the dosage of inulin $5 \%$ by weight of the flour, the specific volume of the products from inulin is $8.5 \%$ higher than the control sample. This can be explained by the fact that the introduction of inulin into the dough improves its elasticity and allows to obtain a larger volume of finished products and improves the fermentation activity of yeast due to the enrichment of fructose in the liquid phase of the dough.

The effect of inulin made from chicory on the quality of finished products, $n=3, p \leq 0.95$

\begin{tabular}{|c|c|c|c|c|}
\hline \multirow[t]{2}{*}{ Indicator } & \multirow[t]{2}{*}{ Contral } & \multicolumn{3}{|c|}{$\begin{array}{l}\text { Added inulin made from chicory } \\
\text { (on dry substances) \% by weight } \\
\text { of flour }\end{array}$} \\
\hline & & 5 & 10 & 15 \\
\hline Specific volume, $\mathrm{cm}^{3} / \mathrm{g}$ & 3.36 & 3.67 & 3.29 & 2.86 \\
\hline Formability, $\mathrm{H} / \mathrm{D}$ & 0.41 & 0.47 & 0.51 & 0.57 \\
\hline Porasity, \% & 72 & 74 & 72 & 71 \\
\hline $\begin{array}{l}\text { Penetration of the crumb, } \\
\text { units appliance }\end{array}$ & 108 & 120 & 88 & 51 \\
\hline Surface condition & \multicolumn{4}{|c|}{ Smooth without cracks } \\
\hline Crust color & Light colored & Light yellow & $\begin{array}{l}\text { Golden } \\
\text { yellow }\end{array}$ & Yellow \\
\hline Сrumb condition & Elastic & Elastic & $\begin{array}{c}\text { More } \\
\text { resilient } \\
\text { than con- } \\
\text { trol and } \\
\text { sample 2 }\end{array}$ & \begin{tabular}{|c} 
More \\
resilient \\
than \\
previous \\
speci- \\
mens \\
\end{tabular} \\
\hline Porosity structure & $\begin{array}{c}\text { Small, } \\
\text { uniform, } \\
\text { developed, } \\
\text { thin-walled }\end{array}$ & \multicolumn{3}{|c|}{$\begin{array}{l}\text { Medium, uniform, developed, } \\
\text { thin-walled }\end{array}$} \\
\hline Taste and aroma & \multicolumn{4}{|c|}{$\begin{array}{l}\text { Peculiar to this product, without unnecessary } \\
\text { tastes and aroma }\end{array}$} \\
\hline
\end{tabular}
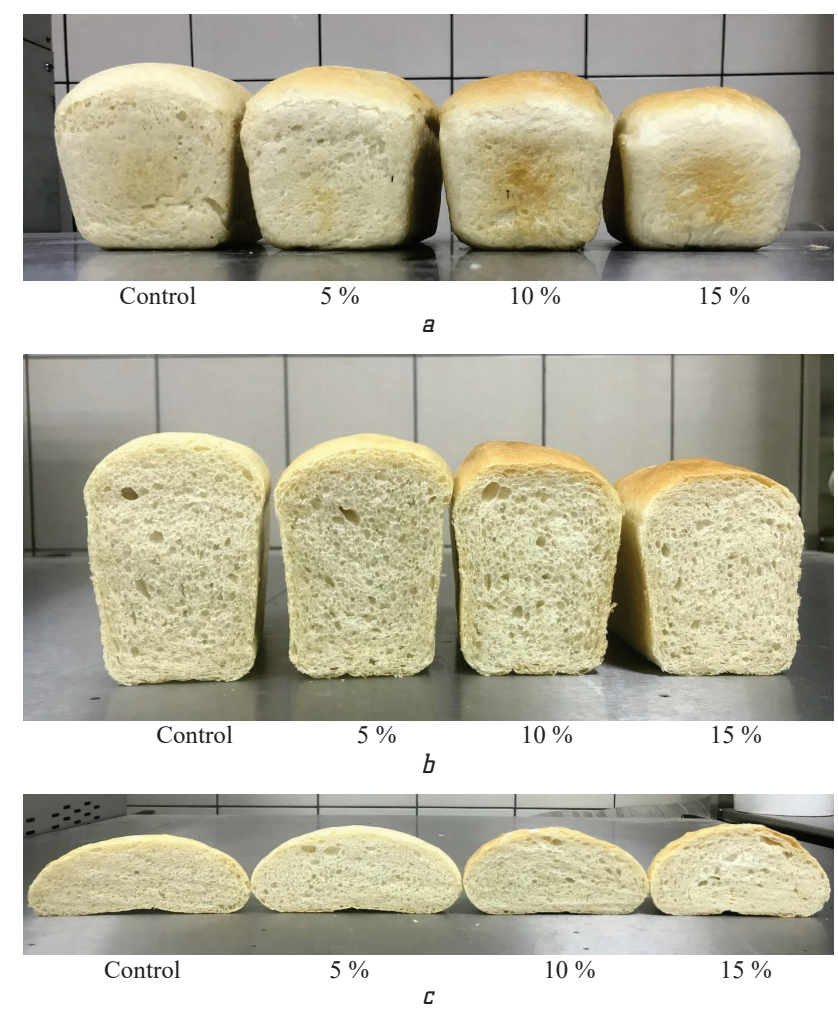

Fig. 3. Photo of bread of the control sample and with the addition of inulin made from chicory in the amount of 5, 10, $15 \%$ by weight of flour: $a$ - pan; $b$ - pan in section; $c$ - over bottom 
At a dosage of $10 \%$ by weight of the flour, the specific volume of products decreases, but only by $2 \%$, while in the sample with $15 \%$ inulin, the specific volume decreases by $15 \%$. For this dosage, a significant increase in the formstability of finished products is observed, which is caused by an increase in the elastic characteristics of the dough at a dosage of inulin of $10 \%$ or more. This assumption is confirmed by changes in the structural and mechanical properties of the crumb of products, namely, organoleptic noted that with increasing dose of inulin, the elasticity of the crumb of products increases. The results of the penetration of the crumb products confirm the growth of its elastic characteristics. So, at the dosage of inulin $10 \%$ by weight of flour - by $18.5 \%$, and by dosing $15 \%$ by weight of flour - by $52 \%$.

\section{Conclusions}

The results of the research prove the effectiveness of using inulin to improve the quality of finished products by dosing $5 \%$ by weight of flour. For greater enrichment of bakery products with dietary fiber, it is recommended to use the dosage of inulin $10 \%$ by weight of flour, but to apply technological measures to improve the quality of the products.

It is established that a decrease in the specific volume of products and an increase in the elastic characteristics of the crumb are the limiting factors of using inulin products in the formulation in an amount of more than $10 \%$ by weight of the flour.

It is established that the addition of inulin from chicory leads to an increase in the elastic properties of the dough, especially with an increase in the dose of inulin over $10 \%$. Increasing the dose of inulin made from chicory to $15 \%$ or more along with an increase in the elastic characteristics reduces the dough elasticity, leading to a significant deterioration in the volume of products.

\section{References}

1. Bashta A. O., Ivchuk N. P. Perspektyvy vykorystannia inulinovmisnoi syrovyny $\mathrm{v}$ profilaktytsi neinfektsiinykh khronichnykh zakhvoriuvan. Rozrobka tekhnolohii pshenychnoho khliba z pidvyshchenoiu kharchovoiu tsinnistiu // Problemy starenyia y dolholetyia. 2016. Vol. 25, Issue 2. P. 222-229.

2. Terenda N. O. Smertnist vid sertsevo-sudynnykh zakhvoriuvan yak derzhavna problema // Visnyk naukovykh doslidzhen DVNZ «Ternopilskyi derzhavnyi medychnyi universytet imeni I. Ya. Horbachevskoho». 2015. Issue 4. P.11-13.

3. Inulin-type fructans: A review on different aspects of biochemical and pharmaceutical technology / Apolinário A. C., de Lima Damasceno B. P. G., de Macêdo Beltrão N. E., Pessoa A., Converti A., da Silva J. A. // Carbohydrate Polymers. 2014. Vol. 101. P. 368-378. doi: http://doi.org/10.1016/j.carbpol.2013.09.081

4. Cummings J. H., Macfarlane G. T., Englyst H. N. Prebiotic digestion and fermentation // The American Journal of Clinical Nutrition. 2001. Vol. 73, Issue 2. P. 415-420. doi: http:// doi.org/10.1093/ajcn/73.2.415s
5. Liu J., Willför S., Xu C. A review of bioactive plant polysaccharides: Biological activities, functionalization, and biomedical applications // Bioactive Carbohydrates and Dietary Fibre. 2015. Vol. 5, Issue 1. P. 31-61. doi: http://doi.org/10.1016/ j.bcdf.2014.12.001

6. Morris C., Morris G. A. The effect of inulin and fructo-oligosaccharide supplementation on the textural, rheological and sensory properties of bread and their role in weight management: A review // Food Chemistry. 2012. Vol. 133, Issue 2. P. 237-248. doi: http://doi.org/10.1016/j.foodchem.2012.01.027

7. Influence of inulin on physical characteristics and staling rate of gluten-free bread / Ziobro R., Korus J., Juszczak L., Witczak T. // Journal of Food Engineering. 2013. Vol. 116, Issue 1. P. 21-27. doi: http://doi.org/10.1016/j.jfoodeng.2012.10.049

8. Salinas M. V., Puppo M. C. Optimization of the formulation of nutritional breads based on calcium carbonate and inulin // LWT - Food Science and Technology. 2015. Vol. 60, Issue 1. P. 95-101. doi: http://doi.org/10.1016/j.lwt.2014.08.019

9. Fibre enrichment of wheat bread with Jerusalem artichoke inulin: Effect on dough rheology and bread quality / Rubel I. A., Pérez E. E., Manrique G. D., Genovese D. B. // Food Structure. 2015. Vol. 3. P. 21-29. doi: http://doi.org/10.1016/ j.foostr.2014.11.001

10. Sirbu A., Arghire C. Functional bread: Effect of inulin-type products addition on dough rheology and bread quality // Journal of Cereal Science. 2017. Vol. 75. P. 220-227. doi: http://doi.org/ 10.1016/j.jcs.2017.03.029

11. Lebedenko T. Ie., Pshenyshniuk H. F., Sokolova N. Iu. Tekhnolohiia khlibopekarskoho vyrobnytstva. Praktykum: textbook. Odessa: Osvita Ukrainy, 2014. 392 p.

12. Tekhnokhimichnyi kontrol syrovyny ta khlibobulochnykh i makaronnykh vyrobiv: textbook / ed. Drobot V. I. Kyiv: NUKhT, 2015. 902 p.

Bondarenko Yulia, PhD, Associate Professor, Department of Bakery and Confectionary Goods Technology, National University of Food Technologies, Kyiv, Ukraine, e-mail: bjuly@ukr.net, ORCID: http:// orcid.org/0000-0002-3781-5604

Bilyk Olena, PhD, Associate Professor, Department of Bakery and Confectionary Goods Technology, National University of Food Technologies, Kyiv, Ukraine, e-mail: bilyklena@gmail.com, ORCID: http:// orcid.org/0000-0003-3606-1254

Kochubei-Lytoynenko Oksana, PhD, Associate Professor, Department of Milk and Dairy Technology, National University of Food Technologies, Kyiv, Ukraine, e-mail: okolit@email.ua, ORCID: http:// orcid.org/0000-0003-0712-448X

Khalikova Esma, Department of Food Expertise, National University of Food Technologies, Kyiv, Ukraine, e-mail: esma7@ukr.net, ORCID: http://orcid.org/0000-0001-5785-1306

Fain Albina, Lecturer, Department of Information Activities, Documentation and Fundamental Disciplines, Podilsky Special EducationalRehabilitation Socio-Economic College, Kamianets-Podilsky, Ukraine, e-mail: fainalbina@gmail.com, ORCID: http://orcid.org/0000-00029107-7198 